Hajdu F, Ansell N, Robson E, van Blerk L (2013) 'Rural young people's prospects opportunities for employment and entrepreneurship in globalised southern Africa: the limitations of targeting policies' International Development Planning Review 35(2) 155-174

\title{
Rural young people's opportunities for employment and entrepreneurship in globalised southern Africa: The limitations of targeting policies
}

\author{
Flora Hajdu, Nicola Ansell, Elsbeth Robson, Lorraine van Blerk \\ Forthcoming in International Development Planning Review
}

\begin{abstract}
This paper is based on a study with rural young people in Malawi and Lesotho, focusing on their possibilities to access (self) employment in the face of the various constraints imposed by their poor rural situation. Participatory group exercises combined with individual interviews in two rural villages provided personal stories about jobs/businesses that the young people were engaged in, as well as previous experiences and future plans. Constraints as well as enabling factors working at individual and structural levels were analysed. Policies intended to address the needs of young people tend to seek to target the most vulnerable, often on the basis of individual and household level characteristics (e.g. women, orphans, AIDS-affected households). We argue that this a) neglects the structural factors operating at national and global levels and b) fails to recognise that factors interact to produce vulnerability rather than this being rooted in separate characteristics. We demonstrate that an intersectional approach, drawn from feminist studies, is a useful theoretical lens, which in combination with a livelihoods perspective helps illuminate the needs of rural young people. In situations characterized by high levels of poverty and multiple vulnerabilities, we argue that it can be costly and ineffective to try to decide 'who is most vulnerable', rather, resources can be more effectively spent in trying to improve conditions that will benefit all rural young people.
\end{abstract}

\section{INTRODUCTION}

As discussed in this special issue, young people in rural southern Africa are among the most vulnerable groups in the world with regard to their opportunities to access safe and secure livelihoods based on employment or entrepreneurship. Rural populations in the global South are still often expected to rely mainly on agriculture for their survival, and when their livelihood situations are discussed it is usually adults supporting families who are the main concern. Regarding the situation of young people, policies of governments and international and local development organisations tend to centre on specific groups such as orphans and other vulnerable children (OVCs), rather than on the general struggle of young people in poor circumstances to find (self)employment after leaving school, and the structural factors that make this difficult. 
Hajdu F, Ansell N, Robson E, van Blerk L (2013) 'Rural young people's prospects opportunities for employment and entrepreneurship in globalised southern Africa: the limitations of targeting policies' International Development Planning Review 35(2) 155-174

This paper is based on a study conducted with rural young people (aged 10-24 years) in Malawi and Lesotho, that focused on broadly on the effects that AIDS and other constraints had on their possibilities to secure sustainable livelihoods. For this paper, we have analysed the collected data with a focus on the young people's possibilities to access employment and engage in entrepreneurial activities Constraints, as well as enabling factors, were investigated through personal stories of past and present jobs/business ventures, as well as young people's future plans and prospects.

Our analysis combines a livelihoods perspective with an intersectional approach to probe how the young people are both helped and constrained by individual, structural and global-level factors, which in complex ways interact to create more successful or more vulnerable outcomes. While some individual characteristics, such as age, gender, family situation and social networks are difficult to change, people who share them are often targeted through policy if the characteristics are consistently an indicator of disadvantage. Other individual characteristics such as access to education, skills and capital are more readily addressed through policy, but this might fail to address more significant underlying structural problems that produce vulnerability. In general, the structural processes that cause disadvantage to accrue to people with particular characteristics are seldom themselves addressed. Some structural factors can be addressed at a national level through targeted in-country policies, such as access to work opportunities and employment rights, while structural factors at a global scale, such as changing salaries and opportunities in export sectors, would need to be targeted through broader international policy efforts. The investigation focuses on whether current policies succeed in targeting the most important constraints experienced by rural young people themselves, and questions whether targeting is the best method of addressing the needs of the most vulnerable young people.

\section{POLICY RESPONSES TO YOUNG PEOPLE'S LIVELIHOODS IN SOUTHERN AFRICA}

As pointed out by Bryceson (2010), livelihood studies over the past decade have increasingly shown how rural people in Africa are moving from an agrarian lifestyle and diversifying towards various non-farm incomes, including employment and various small-scale businesses. As a result, core values are changing and today's younger generation, are no longer satisfied with agricultural livelihoods but are aiming to secure wealthier lifestyles through gainful employment or successful self-employment. Such values are very much encouraged in school, where young people are told to aim for employment, and where those who end up engaging in conventional rural livelihood activities despite having gone to school are cast as failures (Ansell, 2004). Whether or not young people actually manage to secure (self)employment varies of course, but 
Hajdu F, Ansell N, Robson E, van Blerk L (2013) 'Rural young people's prospects opportunities for employment and entrepreneurship in globalised southern Africa: the limitations of targeting policies' International Development Planning Review 35(2) 155-174

it is nevertheless the goal towards which they tend to strive and use their scarce resources to try to achieve (Hajdu et al., 2011).

Policies targeting young people's livelihoods in rural southern Africa have not caught up with this trend, and the focus (of resources if not rhetoric) has often been on ensuring their access to formal education (Hajdu et al., 2011). During the past decade there has also been a focus on mitigating the impacts of AIDS, but similarly in this respect the main focus has been on minimising school dropout due to parental sickness and death (Arrehag et al., 2006). In Malawi, for instance, the first 'priority target group' identified in the National Youth Policy (Republic of Malawi, 2010) are orphans and the first 'policy priority area' is education. Furthermore, the National Policy on Orphans and other Vulnerable Children (Government of Malawi, 2003) encourages 'CBOs, NGOs, FBOs, government, companies and others to provide educational support to needy orphans and other vulnerable children' (p. 3). In Lesotho, a secondary school bursary programme for OVCs has been funded by the government, Global Fund and World Bank to the tune of USD 34 million since its inception in 2002 (Global Fund Coordinating Unit 2011). However, several studies suggest that schooling provides few rural southern African young people with access to paid employment (Ansell, 2004) and generally fails to prepare them for the livelihoods in which they will actually engage (Mamdani et al., 2008; Chant and Jones, 2005; Ansell, 2000). Ansell (2004) also shows that schools are not perceived to have a role in preparing all those young people who do not manage to obtain a certificate of completion (which was the vast majority in our study villages) with alternative routes to finding or creating employment. While focusing one-sidedly on education, policies also neglect to address complicated globalscale processes that affect young people's opportunities for employment and entrepreneurship in very specific ways (Langevang and Gough, 2012).

There are two key problems associated with policies targeting young people's livelihoods, which mean that these policies fail to address the constraints and opportunities faced by young people that we discuss later in this paper. The first is an excessive focus on certain categories which are used as the basis for targeting. Women or orphans, for instance, are targeted with loans, bursaries or various projects. Lesotho's National OVC Strategic Plan (Ministry of Health and Social Welfare, 2006), for instance, identifies its targets as:

'orphans, children living in the streets, children with challenging behaviour, children in need of legal and other forms of protection, children who are or have been physically, psychologically, emotionally or sexually abused, neglected children, those involved in child labour, children with disabilities, those in commercial sex work, who frequent the company of immoral persons, those affected and infected by HIV/AIDS and other chronic 
Hajdu F, Ansell N, Robson E, van Blerk L (2013) 'Rural young people's prospects opportunities for employment and entrepreneurship in globalised southern Africa: the limitations of targeting policies' International Development Planning Review 35(2) 155-174

diseases, those whose parents are delinquent and or who cannot be supervised by adults and the under fives' (p. 6)

Malawi's National Youth Policy (Republic of Malawi, 2010) identifies its priorities as:
‘) Orphans
b) Youth with disabilities
c) Youth living with HIV.
d) Young people on the street.
e) Youth in conflict with the law.
f) Unemployed youth
g) Teenage mothers' (p. 15-16)

The Malawi Growth and Development Strategy (Government of Malawi, 2006) recurrently calls for the economic empowerment of 'Women, youth and the disabled'. Some of these targeted categories are arguably very broad, and the risk is that if almost everyone is a priority, then nobody really is.

Targeting particular categories in this way can lead to an undue identification of a particular group with vulnerability. For example, Ansell (2010) shows how Lesotho's bursary scheme associates orphanhood in general with vulnerability to an excessive extent. Categories and groups are unlikely to be so homogeneous and such an approach may also unnecessarily trigger negative stigmatisation of the targeted group. Skovdal (2012) argues against dominant constructions of a 'normal' childhood that casts many African children and especially AIDS orphans as 'abnormal' and potentially 'troubled', even showing how this discourse leads to scientific studies drawing conclusions about orphans in general suffering from mental problems and predicting crime-waves when they grow up.

A further problem is that such policies give the impression that only a certain category of people have difficulties or are in need of help, thus seemingly 'containing' a problem that is actually not contained. For example, most young people in poor rural areas might struggle to get through school due to economic problems, whether their parents are healthy or not, and targeting only orphans with bursaries creates the impression that other non-orphans can manage without help. It is therefore important that targeting of groups is carefully considered, and only used if there is sufficient reason to believe that an entire group is indeed disadvantaged systematically. We argue that using the theoretical framework of intersectionality can help to draw attention to how people can be positioned in several categories simultaneously, and how vulnerability is often the result of a complex interaction of multiple factors. 
Hajdu F, Ansell N, Robson E, van Blerk L (2013) 'Rural young people's prospects opportunities for employment and entrepreneurship in globalised southern Africa: the limitations of targeting policies' International Development Planning Review 35(2) 155-174

A second, related problem with policy responses to young people's livelihoods is the neglect of structural factors. If young people with particular characteristics are targeted, the interventions are intended to ameliorate the conditions of those individuals, not to address the wider processes that cause, for instance, youth to be unemployed, or teenage mothers to face particular difficulties. Ignoring the effects of structural processes on local opportunities, poverty and inequality has been common in development contexts, which Ferguson (1990) argues is because it conveniently de-politicises problems, and also favours simple, quick fixes such as technology transfer (Rigg, 2006). However, as pointed out by both Scott (1998) and Li (2007), attempts at development often fail since planning ignores complex realities, is oversimplified and disregards the impossibility of knowing beforehand exactly the consequences interventions might have. In general, then, policies appear too heavily reliant on the targeting of young people based on certain individual characteristics, and too little on the structural conditions that shape livelihood opportunities.

\section{LIVELIHOODS PERSPECTIVE AND INTERSECTIONAL ANALYSIS}

In examining young people's economic engagement and future prospects in relation to these policy interventions, we used a livelihoods perspective, with a corresponding focus on participatory data collection. We combined this with an intersectional approach in data analysis. A livelihoods perspective focuses on the realities experienced by local people from their own point of view (Scoones, 2009 Chambers and Conway, 1992), which is highly useful when assessing young people's experiences and future plans. Intersectionality is useful in analysis, allowing deeper investigation of how various factors interact in complex ways in the individual lives of young people to produce more or less vulnerable or successful outcomes.

Intersectionality has its roots in feminist sociology and the term was first introduced by Crenshaw (1989), who pointed out that the tendency of gender-based and race-based theory was to simplify a complex reality by categorising people by one characteristic only. While feminist studies focused largely on white women, race studies focused mostly on black men, and a black woman's experience, at the intersection between race and gender, could not be understood through the available concepts. Something new was thus needed, and intersectionality with its focus on multiple categories of social identity and how they intersect to produce new dynamics was the answer. The concept thus has a 'bottom -up' quality, in that it has arisen from observation and analysis of everyday practices (Phoenix, 2011).

While some of the work on intersectionality aims to deconstruct categorical divisions, other approaches work with traditional categories but aim to reveal diversity and differences within these groups and focus on the process through which categories are produced, reproduced and resisted (McCall, 2005). According to Phoenix (2011), a major contribution of intersectional 
Hajdu F, Ansell N, Robson E, van Blerk L (2013) 'Rural young people's prospects opportunities for employment and entrepreneurship in globalised southern Africa: the limitations of targeting policies' International Development Planning Review 35(2) 155-174

analysis is that it recognises the importance of analysing the ways in which people are simultaneously positioned in multiple categories of identity.

Although intersectionality has recently almost become a 'buzzword' (Davis, 2011), it has not usually been combined with a livelihoods perspective. However, it has been underscored in livelihoods studies that it is important not to neglect consideration of various types of local stratifications when analysing livelihoods (de Haan and Zoomers, 2005; Platteau, 2004). Goebel (1998) notes that while she focused on investigating gender relations using participatory methods in rural Zimbabwe, this focus led to the neglect of other important power relations, such as clan, wealth, relationship to the ruling party and witchcraft. In relation to our study's focus on young people, age in rural southern Africa is perhaps the most important type of stratification of all. Many relations are strictly hierarchical based on age, and there are very strong cultural norms dictating behaviour, appropriate topics of discussion, etc. between different age groups (Hajdu, 2006; Ncube, 1998 ). In this study, we used intersectionality mainly to look at how young people are both helped and constrained by various combinations of, for example, their gender, age, social status, educational level or marital status when it comes to gaining access to livelihoods.

\section{CASE STUDY}

The remainder of this paper is based on empirical research that reveals some of the key constraints and enabling factors that young people experience as they seek to establish livelihoods for themselves. The fieldwork was undertaken within the framework of a wider project exploring AIDS' effects on young people's livelihoods in southern Africa. Two case study countries, Malawi and Lesotho, were selected. In both, there is a general concern among government ministries, donors and NGOs for orphans and other vulnerable children, as well as for young people's general lack of employment opportunities. These issues are difficult to target, however, and tools such as national youth policies tend to resemble wish lists that are unlikely to have substantive effects on young people's lives (see further in Ansell et al. (2012)). In both countries, access to formal education heads the agenda when it comes to policies for improving young people's livelihoods (Hajdu et al., 2011). Bursaries for orphans to go to secondary school are consequently a common intervention from government and from a range of different NGOs of various sizes and forms (including even local rural churches).

A small village was selected in each country for in-depth research with young people. This case study approach facilitated much deeper understanding of young people's lives over time, and 
Hajdu F, Ansell N, Robson E, van Blerk L (2013) 'Rural young people's prospects opportunities for employment and entrepreneurship in globalised southern Africa: the limitations of targeting policies' International Development Planning Review 35(2) 155-174

their relationships with peers and adults, than would have been possible had attention been spread across more diverse locations.

Both villages were selected on the basis that they are relatively typical of their respective countries, and both are located in regions with relatively high HIV prevalence. Both are some distance from the closest tarmac road and neither had experienced any significant development project within the locality in recent years. The Malawian village (Nihelo) is located in the densely populated Shire highland district of Thyolo, where subsistence agriculture plays an important role for livelihood security. Local markets and small-scale businesses abound, especially carpentry and various 'repair' businesses, such as bicycle repairs, sewing and radio repairs. The general level of poverty is very high, however, limiting the economic feasibility of such businesses. Local employment opportunities mainly consist of seasonal labour at tea plantations, but it is also common for people to migrate to towns and cities to do domestic work.

In contrast, the Lesotho village (Ha Rantelali) is located in the very sparsely populated Maluti Mountains, where livestock herding and labour outmigration to South African mines have historically provided for the population, while agriculture has had a lesser role. However, the mines have laid off people at an rapid rate during the past decade, and people from Lesotho are disproportionately affected as they are foreigners in South Africa. A garment industry has instead expanded on the outskirts of Lesotho's capital city, Maseru, but in this industry, which mainly employs women, wages are very low and contracts insecure compared with the previous mine work opportunities (Chaka, 2011). Small-scale businesses are uncommon in the Lesotho highlands, a result of sparse population, the historical reliance on 'proper' work and the problem of cheap manufactured goods from South Africa flooding the market at prices with which local carpenters and repair businesses cannot compete (Hajdu et al., 2011).

In Malawi, Nihelo comprised 253 persons at the time of the research (late 2007), of whom 70 were young people aged 10-24 years. In Lesotho, Ha Rantelali consisted of 169 persons in early 2008, of whom 79 were 10- to 24-year-olds. The higher proportion of young people in the Lesotho village is probably partly due to higher AIDS prevalence rates causing deaths among the older age groups. Another reason is that migration for work starts at a later age in Lesotho than in Malawi due to a later average age at first marriage.

\section{METHODS}

\section{Data collection}

Fieldwork for this project was conducted in two phases. During the first village-based fieldwork period of 3-4 months in each country, the main field researcher (surname withheld) resided in 
Hajdu F, Ansell N, Robson E, van Blerk L (2013) 'Rural young people's prospects opportunities for employment and entrepreneurship in globalised southern Africa: the limitations of targeting policies' International Development Planning Review 35(2) 155-174

the study villages, while the other researchers made several village visits to participate in various parts of the field research. A second phase, where the research team returned for a week to each village to carry out follow-up fieldwork and disseminate findings, took place 5-8 months later.

Access to communities was negotiated through local authorities and community participation was encouraged through rapport building. Two community meetings and a dissemination workshop, all including participatory exercises and opportunities for questions and feedback, were held in each community. Each household was interviewed to record presence of young people, experiences of sickness and death in the family and livelihood activities. Research assistants were recruited locally in both countries.

We focused on the experiences of young people aged 10-24, as this period spans most young people's transitions from childhood to adulthood (leaving school, leaving home, marriage, parenthood). Defining young people in chronological terms is not easy, and chronological age classifications seldom closely reflect young people's experiences. Lesotho and Malawi have differing official definitions and diverse classifications are employed across different institutions and policies in both countries. Thus the classification adopted in cross-national research is inevitably somewhat arbitrary.

Young people aged $10-24^{1}$ in each village were informed about the project and invited to participate. Those who volunteered to participate were divided into four groups based on age and gender. Those still legally children (under 18 and predominantly still attending school) participated separately from young adults (aged 18-24, most of whom focused full-time on their immediate livelihoods, and many of whom were married). Grouping the young people in this way facilitated discussions, by increasing the homogeneity of both interest and status.

Each group attended 10 participatory sessions to express their opinions and thoughts, share experiences and discuss important issues. Activities included drawing life maps and social network charts, doing guided village walks and working with photography and drama. More than $50 \%$ of all $10-24$-year-olds in both villages participated. In-depth individual interviews were then conducted with all young people aged 18-24 who were available in the villages and willing to be interviewed during the second fieldwork period. The information from all these different sources was pooled for every young person, producing individual stories that could be analysed from various perspectives (Kearney, 2002). In total, the participants comprised 42 young people

\footnotetext{
${ }^{1}$ The precise age of young people in Malawi was not easy to establish, and during the course of the research it became apparent that some of the young research participants were older or younger than initially suggested.
} 
Hajdu F, Ansell N, Robson E, van Blerk L (2013) 'Rural young people's prospects opportunities for employment and entrepreneurship in globalised southern Africa: the limitations of targeting policies' International Development Planning Review 35(2) 155-174

from Lesotho (23 aged 10-17; 19 aged 18-24) and 50 from Malawi (20 aged 10-17; 30 aged 1824).

Table 1 shows the total number of young people in each country participating in the study and a numerical breakdown of their past and present experiences of employment or informal business ventures (self-employment), as well as their future plans. In Malawi, young people who had employment were not living in the village (or had a very long walk to and from work), and hence could not take part in the research. Therefore, the data obtained on employment were mainly about past experiences. In Lesotho, a few women and men were employed in the village, usually as domestic workers for other families or as herd boys.

Table 1. Young people's past/present experiences and future plans for (self)employment

\begin{tabular}{|l|l|l|l|l|l|}
\hline \multicolumn{2}{|c|}{} & \multicolumn{2}{l|}{ Malawi (no. of experiences) } & \multicolumn{2}{l|}{ Lesotho (no. of experiences) } \\
\hline \multirow{2}{*}{ Time frame } & Employment type & $\begin{array}{l}\text { Women } \\
(\text { total 29) }\end{array}$ & $\begin{array}{l}\text { Men } \\
\text { (total 21) }\end{array}$ & $\begin{array}{l}\text { Women } \\
\text { (total 21) }\end{array}$ & $\begin{array}{l}\text { Men } \\
\text { (total 21) }\end{array}$ \\
\hline Current situation & Employment & - & - & 2 & 7 \\
\cline { 2 - 7 } & Self-employment & 3 & 2 & - & 1 \\
\hline Past experience & Employment & 16 & 9 & 8 & 5 \\
\cline { 2 - 7 } & Self-employment & 3 & 2 & 1 & - \\
\hline Future plans & Employment & - & 1 & - & 3 \\
\cline { 2 - 6 } & Self-employment & 8 & 1 & 3 & 2 \\
\hline
\end{tabular}

Married men in Malawi are expected to focus on working or trying to find work to support their families, which meant that young men in Malawi were difficult to recruit for participatory research activities (although many participated in interviews). In Lesotho, where the average age of marriage for men is significantly later than in southern Malawi due to bridewealth practices, the young men were still mostly unmarried and thus had fewer responsibilities. Many

\footnotetext{
${ }^{2}$ To clarify, a total of 29 women in Malawi contributed to the research, but many had no experience at all from either work or business. While 16 female past experiences of work were recorded, one person may have had several experiences. The experiences could be positive or negative (for example looking for work but failing to find it).
} 
Hajdu F, Ansell N, Robson E, van Blerk L (2013) 'Rural young people's prospects opportunities for employment and entrepreneurship in globalised southern Africa: the limitations of targeting policies' International Development Planning Review 35(2) 155-174

were engaged in herding, but we made special efforts to gather the herders for activities during visits to the cattle post in the summer pastures some distance from the village. Young married women in both countries usually expected to be supported by their husbands in the future, and therefore had plans mainly for small business activities.

\section{Data analysis}

For this paper, our information about each person with past or present experience of, or future plans for, a job (employment) or an enterprise (self-employment) was analysed. The factors mentioned by the young people themselves as contributing to success (e.g. social connections) and constraints that were either overcome or that had contributed to failure, were listed. With regard to future plans, the young people's own reflections on constraints or resources were listed instead. The youngest participants seldom had previous experience to report, and their plans for the future are only included here if these seemed feasible, as many talked about unrealistic dreams rather than concrete plans.

The constraints/enabling factors were allocated to four categories: 1 ) individual factors, such as age, gender, sickness/death in the family, or social connections that are largely immutable they cannot be readily changed through government policy, although they are often the basis for targeted interventions ${ }^{3}$; 2 ) individual factors that are responsive to interventions such as education and skill levels and access to assets; 3 ) structural-national factors, such as, work opportunities and employment rights; and 4) structural global-scale factors, where the young person in question had identified some form of connection to a global-level issue, such as lack of suitable opportunities or lack of a market for a certain business. Dividing factors between scales in this way is problematic, and many factors operate across multiple scales. While we classify gender as an individual attribute, for instance, the way in which it shapes livelihoods reflects national and global level structural processes. The purpose of our categorisation is to relate the constraints and enabling factors to common policy interventions. Policies, for instance, often target those deemed to be disadvantaged by immutable individual characteristics such as gender or orphanhood with remedial assistance, but could also address the structural conditions that operate on these characteristics such as gender discrimination, AIDS-related stigma or lack of employment rights. Where young people are disadvantaged by individual characteristics that can be addressed directly through policy such as lack of education, there might also be a need for wider structural change: the value of education is strongly shaped by labour market conditions. Finally, constraints and enabling factors were listed for the young people, and we then analysed how these factors had interacted to produce

\footnotetext{
${ }^{3}$ Incidence of sickness and death can be altered through health policy, but only to a limited extent.
} 
Hajdu F, Ansell N, Robson E, van Blerk L (2013) 'Rural young people's prospects opportunities for employment and entrepreneurship in globalised southern Africa: the limitations of targeting policies' International Development Planning Review 35(2) 155-174

the situations of the most successful and the most vulnerable young people in both villages with respect to livelihood strategies and outcomes.

\section{TYPES OF CONSTRAINTS AND ENABLING FACTORS EXPERIENCED BY YOUNG PEOPLE}

Young people's opportunities for employment and entrepreneurship reflect both constraints and enabling factors. In analysing the young people's experiences, we categorised constraints and enabling factors and grouped them into the four main groups listed above, as shown in Table 2 (constraints) and Table 3 (enabling factors). The tables provide information on the number of young people experiencing each category of constraint/enabling factor and quotations exemplify the way they conceptualised their experiences.

With regard to individual immutable factors, surprisingly few young people attributed difficulties in securing livelihoods to age- or gender-related constraints (Table 2), though discrimination often works at a structural level and can be difficult to perceive as an individual. Women (on the basis of their gender) are vulnerable to sexual assaults in the workplace, and this was a common reason for leaving an otherwise promising job in Malawi. This issue can also be related to the generally weak rights of employees, discussed further below. In Lesotho, young women felt more inhibited by their husbands and their husbands' families than in Malawi. This can be explained by differences in practices after marriage, where newly married couples are expected to live with the husband's family for several years in Lesotho. In contrast, in southern Malawi the husband usually moves to the wife's village and the couple make a household for themselves ${ }^{4}$.

Table 2. Common constraints for young people in Malawi and Lesotho

\begin{tabular}{|l|l|l|l|}
\hline Category & Malawi & Lesotho & Examples \\
\hline 1. INDIVIDUAL FACTORS-IMMUTABLE \\
\hline $\begin{array}{l}\text { Age-related } \\
\text { problems }\end{array}$ & 2 & & $\begin{array}{l}\text { 'Too hard work for a } 10 \text { year old led to quitting', 'They didn't } \\
\text { want to employ me because I was too young'. }\end{array}$ \\
\hline
\end{tabular}

\footnotetext{
${ }^{4}$ The Malawian village is in an area where matrilineal practices dominate, meaning that land and property are transferred through the female line, from mothers to daughters, leading to a preference for uxorilocality (matrilocality), i.e. husbands generally settle in their wives' villages after marriage (see Peters (1997) for more information on matrilineal practices in southern Malawi). In Lesotho, the more common patrilineal patrilocal practice dominates, whereby land and property are passed from fathers to sons, and women are expected to move in with their husbands' families upon marriage.
} 
Hajdu F, Ansell N, Robson E, van Blerk L (2013) 'Rural young people's prospects opportunities for employment and entrepreneurship in globalised southern Africa: the limitations of targeting policies' International Development Planning Review 35(2) 155-174

\begin{tabular}{|c|c|c|c|}
\hline $\begin{array}{l}\text { Gender-related } \\
\text { problems }\end{array}$ & 3 & 4 & $\begin{array}{l}\text { 'My husband doesn't want me to work after marriage', } \\
\text { 'Pregnancy caused me to quit that work', 'Employer wanted to } \\
\text { have sex, so I ran away/his wife chased me away' }\end{array}$ \\
\hline Family situation & 2 & 2 & $\begin{array}{l}\text { 'My mother wanted me to help around the house so I couldn't } \\
\text { look for work', 'There is nobody else to look after our cattle so I } \\
\text { can't look for work' }\end{array}$ \\
\hline No connections & & 1 & 'I don't know anybody who could find me work' \\
\hline \multicolumn{4}{|c|}{ 2. INDIVIDUAL FACTORS-RESPONSIVE TO INTERVENTION } \\
\hline $\begin{array}{l}\text { Lack of business } \\
\text { skills }\end{array}$ & 3 & & $\begin{array}{l}\text { 'I thought I was making profit, but when I counted the money I } \\
\text { found that I was losing', 'I ate the capital' }\end{array}$ \\
\hline $\begin{array}{l}\text { Lack of capital/ } \\
\text { assets to start } \\
\text { business }\end{array}$ & 6 & 4 & $\begin{array}{l}\text { 'Would need a bicycle for the business but it is broken', 'There } \\
\text { is no money to restart the business' }\end{array}$ \\
\hline
\end{tabular}

\section{STRUCTURAL-NATIONAL FACTORS}

\begin{tabular}{|l|l|l|l|}
\hline $\begin{array}{l}\text { Lack of access to } \\
\text { banking }\end{array}$ & 1 & \multicolumn{2}{|c|}{$\begin{array}{l}\text { 'I gave the money to a friend to keep it safe for me, but he was } \\
\text { in a car accident and used the money to pay for hospital care' }\end{array}$} \\
$\begin{array}{l}\text { Crime } \\
\text { (Theft/robbery) }\end{array}$ & 1 & 1 & 'They stole my earnings since I was a stranger' \\
\hline $\begin{array}{l}\text { Employment } \\
\text { rights }\end{array}$ & $\mathbf{1 5}$ & $\mathbf{4}$ & $\begin{array}{l}\text { 'Employer wanted sex so I ran away ', 'They laid people off after } \\
\text { a few months so they wouldn't have to pay benefits' }\end{array}$ \\
$\begin{array}{l}\text { Transportation } \\
\text { 4. STRUCTURAL-GLOBAL FACTORS }\end{array}$ & 1 & 'It was too far to walk so I had to quit' \\
\hline $\begin{array}{l}\text { Lack of } \\
\text { opportunity }\end{array}$ & 1 & 1 & 'Not enough work for everyone' \\
\hline $\begin{array}{l}\text { No market for } \\
\text { business }\end{array}$ & 1 & 1 & 'There is no market for such business' \\
\hline
\end{tabular}

Contradictory to our expectations, the incidence of sickness and death in the family, sometimes thought to be a major constraint for young people was not cited as a cause for difficulties in finding work or starting up businesses by the young people. This was even though this issue was thoroughly probed given the main focus of the study on AIDS effects on livelihoods. Rather, death in the family was likely to prompt relatives to try to help find work for a young person who now needed to fend for themselves. Therefore 'death in the family' operated as an 'enabling factor' behind finding work for three young people in Lesotho (Table 3).

The importance of social networks for acquiring work and starting up businesses is very clear in the data, with as many as 39 instances of this being mentioned as an enabling factor by the young people themselves (Table 3). Although not many complained that lack of connections 
Hajdu F, Ansell N, Robson E, van Blerk L (2013) 'Rural young people's prospects opportunities for employment and entrepreneurship in globalised southern Africa: the limitations of targeting policies' International Development Planning Review 35(2) 155-174

were a constraint, this is very likely given the importance of social networks as enabling factors. The young people also complained about corruption as a constraint (Table 2), which includes not knowing the right people to talk to in order to get a job, and about that people who were strangers in a village or in a new workplace were mistreated in various ways.

Table 3. Common enabling factors for young people in Malawi and Lesotho

\begin{tabular}{|c|c|c|c|}
\hline Category & Malawi & Lesotho & Examples \\
\hline \multicolumn{4}{|c|}{ 1. INDIVIDUAL FACTORS-IMMUTABLE } \\
\hline Social networks & 23 & 16 & $\begin{array}{l}\text { 'A friend found me the job', 'My uncle loaned me money for the } \\
\text { business' }\end{array}$ \\
\hline $\begin{array}{l}\text { Death in the } \\
\text { family }\end{array}$ & - & 3 & $\begin{array}{l}\text { 'Since my father died, my mother took me to work as a herdboy } \\
\text { for another family' }\end{array}$ \\
\hline \multicolumn{4}{|c|}{ 2. INDIVIDUAL FACTORS-RESPONSIVE TO INTERVENTION } \\
\hline Educational level & & 1 & 'Secondary schooling was required for the job and I had it' \\
\hline Having an asset & 1 & & $\begin{array}{l}\text { 'Having a plot near the stream gave me the opportunity to } \\
\text { irrigate tomatoes' }\end{array}$ \\
\hline $\begin{array}{l}\text { Skills training } \\
\text { opportunity }\end{array}$ & - & 4 & $\begin{array}{l}\text { 'I learned from people in Maseru, I paid them', 'I learnt } \\
\text { craftwork at initiation school' }\end{array}$ \\
\hline \multicolumn{4}{|c|}{ 3. STRUCTURAL-NATIONAL FACTORS } \\
\hline $\begin{array}{l}\text { Work } \\
\text { opportunities }\end{array}$ & 4 & 2 & $\begin{array}{l}\text { 'I worked at the tea estate and used the earnings to start the } \\
\text { business' }\end{array}$ \\
\hline \multicolumn{4}{|c|}{ 4. STRUCTURAL-GLOBAL FACTORS } \\
\hline $\begin{array}{l}\text { Market } \\
\text { opportunities }\end{array}$ & 1 & 1 & $\begin{array}{l}\text { 'I understood that there would be a market for coffins in that } \\
\text { village' }\end{array}$ \\
\hline
\end{tabular}

With regard to individual factors that are amenable to policy, a number of young people explained that they were constrained by a lack of capital, assets or skills. Equally, several had been able to make use of their access to these advantages (compare Tables 2 and 3). These are factors that could be targeted at a national level through interventions providing skills training opportunities coupled with start-up grants. Only one person had found work due to their educational level, and nobody mentioned inadequate education as a constraint (although people might not look for work for which they are not qualified). However, this suggests that qualified work opportunities are scarce, and that focusing on education alone will not do much to help these young people. Rather, structural interventions that expand the labour market might have more significant consequences. 
Hajdu F, Ansell N, Robson E, van Blerk L (2013) 'Rural young people's prospects opportunities for employment and entrepreneurship in globalised southern Africa: the limitations of targeting policies' International Development Planning Review 35(2) 155-174

The most common constraints identified by the young people, however, fell into the category of structural factors at a national level, (Table 2). The majority of these concerned rights related to employment - employers beating or sexually harassing young people, employers not paying the agreed salary or neglecting other aspects, such as not providing whips and gumboots for herd boys. A major problem that we see in this context is that most of the work that the young people engage in is informal - both domestic work and herding is generally done informally. This means there are no formal employment rights to fall back on when there is a problem with payment, sexual harassment, beatings and harsh treatment. However, employment rights are a problem also with formal work, for instance at the tea estates in Malawi, where young people complained about the use of short-term hiring to avoid having to pay benefits, or bribery being required in order to get the job in the first place. Seasonality and temporality of jobs are general concerns that fall into this category too. However, even short-term work opportunities or casual labour could help young people save money and start businesses, as the enabling factors suggest (Table 3).

Other factors that pose constraints are infrastructural: absence of banking opportunities or transport. Conversely, access to these enable young people. These structural factors might be addressed through rural banking schemes or improved transportation in rural areas, for example.

While not many of the young participants had the insight to comment on global-scale factors being direct constraints relating to specific experiences with finding jobs or business opportunities locally (Table 2), they did several such factors operating. A general lack of employment opportunities, and extremely low salaries, for example on Malawian tea plantations or in Lesotho garment factories, was often mentioned and should be seen in the context of global trade agreements and the power of transnational corporations in the price negotiations of export goods from producer nations. Furthermore, a major problem according to the young people in Lesotho is layoffs from South African mines, where many men used to migrate for employment. At the same time, trade agreements with South Africa leave Lesotho unprotected from the inflow of cheap manufactured goods, with which, for example, local carpenters are unable to compete. In Lesotho, a woman commented that there was no market for making coffins in Ha Rantelali, which is because it is possible to reach the village by road and thus to bring in cheap coffins from town. In contrast, in a more remote village without passable road access, there is still a market for local carpenters, which presented an opportunity for a young man from Ha Rantelali who was working there as a teacher (Table 3).

In summary, then, young people face varied constraints as a consequence of individual factors, the ways in which structural processes operate on these and also due to more general structural 
Hajdu F, Ansell N, Robson E, van Blerk L (2013) 'Rural young people's prospects opportunities for employment and entrepreneurship in globalised southern Africa: the limitations of targeting policies' International Development Planning Review 35(2) 155-174

conditions that shape the prospects of all young people. In many cases, however, there appears to be a mismatch between the factors that underlie the targeting of policies (orphanhood, access to education) and those that young people identify as shaping their access to (self)employment (social networks, employment rights).

\section{Individual livelihood outcomes from an intersectional perspective}

While structural constraints are clearly important, it is also apparent that some individuals are more seriously affected by these than others. The analysis has also shown that what is enabling for some (such as social connections) can be constraining for others (those who do not have connections). Focusing on constraints and enabling factors only from an aggregated perspective does not explain why certain individuals succeed or become more vulnerable than others. Individual characteristics are significant, but do not shape livelihoods in the simplistic way that many policies appear to suggest. It is in this regard that an intersectional perspective is valuable.

Analysing the data from an intersectional perspective showed that individuals simultaneously belonged to multiple categories of identity and that these interacted to produce more or less vulnerability. Table 4 lists potential constraints and enabling factors for four of the most successful and five of the most vulnerable young people in the case study. As the table shows, vulnerable young people can possess characteristics that could lead to potential success and, conversely, successful young people have often overcome several factors that could have caused them to be vulnerable. By analysing individual stories, it becomes clear that the situation of each individual is a result of the complex interaction of various factors, and that timing is also crucial for the outcome. Mary's ${ }^{5}$ and Emily's stories from Malawi are illustrative examples of this.

Table 4. Examples of successful and vulnerable outcomes for young people in Malawi and Lesotho

\begin{tabular}{|c|c|c|c|}
\hline & $\begin{array}{l}\text { Name } \\
\text { (age, country) }\end{array}$ & Enabling factors & Constraining factors \\
\hline $\begin{array}{l}\text { S } \\
\text { u }\end{array}$ & $\begin{array}{l}\text { Mary } \\
\text { (21 years, } \\
\text { Malawi) }\end{array}$ & $\begin{array}{l}\text { Strong social network (uncle paid } \\
\text { school fees, got church bursary }\end{array}$ & $\begin{array}{l}\text { Gender (very few women manage to } \\
\text { complete secondary school in rural Malawi), } \\
\text { father died }\end{array}$ \\
\hline C & $\begin{array}{l}\text { David } \\
\text { (16 years, } \\
\text { Malawi) }\end{array}$ & $\begin{array}{l}\text { Strong social network (belongs to } \\
\text { chief's clan, aunt supports him) }\end{array}$ & Both mother and father died \\
\hline $\begin{array}{l}\text { f } \\
\mathbf{u}\end{array}$ & $\begin{array}{l}\text { Bereng } \\
\text { (23 years, }\end{array}$ & $\begin{array}{l}\text { Got bursary, completed secondary } \\
\text { education, has work as teacher, paid }\end{array}$ & Weak social network (new in village), both \\
\hline
\end{tabular}

\footnotetext{
${ }^{5}$ Pseudonyms are used to protect the identities of research participants.
} 
Hajdu F, Ansell N, Robson E, van Blerk L (2013) 'Rural young people's prospects opportunities for employment and entrepreneurship in globalised southern Africa: the limitations of targeting policies' International Development Planning Review 35(2) 155-174

\begin{tabular}{|c|c|c|c|}
\hline \multirow[t]{2}{*}{ I } & Lesotho) & $\begin{array}{l}\text { for vocational skills training and has } \\
\text { business skills, Social network (married } \\
\text { shopowner's daughter) }\end{array}$ & parents dead \\
\hline & $\begin{array}{l}\text { Edison } \\
\text { (20 years, } \\
\text { Malawi) }\end{array}$ & $\begin{array}{l}\text { Strong social network (got church } \\
\text { bursary, uncle taught him building), } \\
\text { skill (building houses) }\end{array}$ & $\begin{array}{l}\text { Father died, had to drop out of school to } \\
\text { support his girlfriend when she got pregnant }\end{array}$ \\
\hline \multirow{5}{*}{$\begin{array}{l}\text { V } \\
\text { u } \\
\text { l } \\
\text { n } \\
\text { e } \\
\text { r } \\
\text { a } \\
\text { b } \\
\text { l } \\
\text { e }\end{array}$} & $\begin{array}{l}\text { Emily } \\
\text { (21 years, } \\
\text { Malawi) }\end{array}$ & $\begin{array}{l}\text { Social network - found job through } \\
\text { networks }\end{array}$ & $\begin{array}{l}\text { Gender (needed to 'marry well'), death of } \\
\text { father, first husband and child, dropped out } \\
\text { of school after one year }\end{array}$ \\
\hline & $\begin{array}{l}\text { Jamiya } \\
\text { (16 years, } \\
\text { Malawi) }\end{array}$ & $\begin{array}{l}\text { Social network (Rich uncle looks after } \\
\text { her, but only in emergencies) }\end{array}$ & $\begin{array}{l}\text { Gender (abandoned by husband), father and } \\
\text { mother dead, has young child who is sick }\end{array}$ \\
\hline & $\begin{array}{l}\text { Rex } \\
\text { (26 years, } \\
\text { Malawi) }\end{array}$ & $\begin{array}{l}\text { Educational level (finished primary } \\
\text { school) }\end{array}$ & $\begin{array}{l}\text { Father and mother dead, weak social } \\
\text { network (new in the village, foreigner) }\end{array}$ \\
\hline & $\begin{array}{l}\text { Momokete } \\
\text { (23 years, } \\
\text { Lesotho) }\end{array}$ & $\begin{array}{l}\text { Social network (her family looks after } \\
\text { her) }\end{array}$ & $\begin{array}{l}\text { Learning difficulties, sick with tuberculosis, } \\
\text { low educational level }\end{array}$ \\
\hline & $\begin{array}{l}\text { Malast } \\
\text { (27 years, } \\
\text { Lesotho) }\end{array}$ & $\begin{array}{l}\text { Social network (has the option to } \\
\text { move home to mother), has work as } \\
\text { domestic worker }\end{array}$ & $\begin{array}{l}\text { Gender (status as separated, employer beats } \\
\text { her), social network (new in the village) }\end{array}$ \\
\hline
\end{tabular}

Mary is one of the most successful young participants in the study in terms of livelihood strategies and outcomes. She had just completed the first year of secondary school, with very good grades, when her father, who had supported the family through work at a tea plantation, died. Mary cried and told her uncle at the funeral that now she would not be able to finish her schooling, upon which the uncle promised to pay her school fees for the next year. On completing another year with good grades, Mary's church, where she was a well-liked and active member, decided to give her a bursary to finish the final two years of secondary school. Belonging to a large extended family, Mary also had a wide social network supporting her with food and shelter so that she could focus on schooling. She succeeded in becoming one of the very few women in Nihelo ever to obtain a completion certificate from secondary school, and is now planning to train as a nurse She thus managed to draw on her social networks to overcome the constraints that her gender and her status as an orphan had imposed on her. However, had she not chanced upon her uncle at the right time when he had money to pay for a year of schooling, her life would certainly have taken a different trajectory upon the death of her father.

Emily, in contrast, was one of the most vulnerable young people in the study. She had dropped out after only one year of primary school, even though her father was alive and making 
Hajdu F, Ansell N, Robson E, van Blerk L (2013) 'Rural young people's prospects opportunities for employment and entrepreneurship in globalised southern Africa: the limitations of targeting policies' International Development Planning Review 35(2) 155-174

reasonable money as a carpenter. The youngest of six children, she experienced poverty as there was no money to buy proper school uniforms or even for soap to wash the clothes with. Her father died when she was 9 years old, at which time she and her brother acquired a shortterm job in town. After this, two different friends helped her to find domestic work in town. The first job was very poorly paid, so she quit after two years. While working in the second home, her employer tried to have sex with her, so she ran away. After earning her own money, Emily considered returning to school, as she was feeling very insecure about not being able to read and write. However, by then she felt that she was too old to join the young children in Standard 2. Instead, she got married, but being a poor, orphaned girl her prospects of a beneficial marriage were poor. Her husband was sickly and died a few years later, leaving her with a small child. Her twin brother took her in for a while, but she was left alone again when he married and moved to his wife's village. A friend then matched her up with a man from Mozambique who was looking for a wife who 'was not too demanding and had already experienced hardship', since he was a poor man (a detailed account of her husband Rex's story has been published elsewhere (Ansell et al., 2011). They had another child together, but the child became sick and died and the husband paid for the funeral, using up the money he was saving to start a business. Emily thus dropped out of school while she was not yet an orphan, and even though she was helped by her social networks several times, these networks were not strong or influential enough to offer her lasting success. The combination of being the youngest of many siblings, having a low educational level and not marrying well left her vulnerable.

The intersectional analysis suggests that targeting categories such as women or orphans is too blunt a tool if the aim is to help the most vulnerable young people. Many more factors are at work in producing successful outcomes or vulnerability in individual young people's lives. If it is necessary to use targeting criteria at all, then using multiple criteria is likely to produce a better outcome. A person who belongs to several categories that are usually associated with greater vulnerability, such as being young, female, disabled, lacking networks, or being affected by sickness or death in the family, is likely to be more vulnerable than someone who shares only a few or none of these characteristics. The stories also reveal the way that chance and timing influence the young people's opportunities (see also Ansell et al., 2011), adding further complexity to the picture and making prediction and identification of vulnerability even more difficult.

\section{ARE POLICIES TARGETING THE MOST IMPORTANT CONSTRAINTS?}

Tthis study only focused on two villages, thus any general conclusions about policy impacts must be tentative. However, the in-depth individual stories of the young people show that their experiences of constraints and vulnerability as well as enabling factors are more complex than 
Hajdu F, Ansell N, Robson E, van Blerk L (2013) 'Rural young people's prospects opportunities for employment and entrepreneurship in globalised southern Africa: the limitations of targeting policies' International Development Planning Review 35(2) 155-174

many policies allow for. Often policies aim to use a clear categorisation based on individual or household level characteristics to determine those in need of assistance and then assist them in very specific ways, rather than addressing the structural factors that render many people vulnerable and some especially vulnerable. Bursaries targeted at orphans are the most common example of this in Malawi and Lesotho currently, and the only significant youthfocused policy intervention to have been applied in both case study villages. In fact, due to the high poverty rate in the villages, orphans were more likely to go to school than non-orphans in both villages, since they had had the possibility to apply for bursaries. However, as discussed earlier, this access to formal schooling did not appear to translate into improved opportunities for (self)employment for these young people.

Our analysis showed that successful or vulnerable livelihood outcomes seldom depend on single factors, but on a complex interaction of individual characteristics and structural factors on both national and global scales. Targeting individuals based on single characteristics, such as being a woman or being an orphan, is likely to be a blunt instrument for identifying the most vulnerable young people. Considering the problems that can be caused by targeting (such as negative stigmatization of those who fall into the targeted groups and undervaluation of the problems of those who do not, as discussed previously), it is perhaps reasonable to question whether the value of targeting indeed outweighs these problems.

The intersectional analysis provides an understanding of how different factors interact, and suggests that young people who belong to multiple categories associated with vulnerability are indeed more likely to be vulnerable. However, intersectionality also highlights complexity and demonstrates that targeting is not necessarily going to result in policies reaching the most vulnerable. It is therefore important to question why policies should get into the thorny business of selecting who deserves help or not in the first place. Policies that try to improve rural livelihoods in general, through for example creating more opportunities for skills training, distance learning, improving transport or strengthening employer rights, are likely to benefit many without spending money on a resource-consuming selection process.

The most important constraints listed by the young people themselves are not the same ones that tend to be the focus of current policy priorities in southern Africa. Even though our study only represents a few young people's voices, this suggests further investigation is merited. While policies focus strongly on formal education and AIDS mitigation, young people's stories suggest that they would benefit most from having more employment/skills training/grant opportunities and from employment rights being more strictly monitored (for example having somewhere to turn to when in conflict with employers, even if the employment is informal). Formal employers could be compelled to take more social responsibility, and to work against 
Hajdu F, Ansell N, Robson E, van Blerk L (2013) 'Rural young people's prospects opportunities for employment and entrepreneurship in globalised southern Africa: the limitations of targeting policies' International Development Planning Review 35(2) 155-174

corruption and nepotism. Although employment rights are categorised in this study as belonging to the structural-national level, many of the issues arising as regards employment can be connected to the global level. Low wages and weak rights in export sectors, such as Malawian tea plantations and Lesotho garment factories, are a result of ruthless international competition and the pressure on prices exerted by powerful multinational companies in order to maximise profit and meet the demand by consumers in the global North for cheap commodities.

Global-scale structural factors would thus also need to be recognised to be issues of concern, even if these are perhaps not something that national government ministries, policy makers or NGOs can do much about. However, ignoring the global dimensions of the problems or focusing one-sidedly on easily amendable factors only serves to reinforce the de-politicisation of these issues. While the young people studied here did not pinpoint global inequalities as constraining factors, it is clear that some very pertinent parts of their everyday lives have close links to the global economy. Such factors include the recent significant rise in unemployment for young men in the Lesotho village due to layoffs in South African mines, and wages so low at the Malawian tea plantations that people are paid more money for casual labour locally. Since the global economic context creates an environment that is already very challenging for young people in rural southern Africa, there are in fact limited opportunities to target individual and structural problems within countries to help them gain access to much needed (self)employment opportunities.

\section{REFERENCES}

ANSELL, N. (2000), 'Sustainability: Life chances and education in southern Africa', Sustainability: Life Chances and Livelihoods. Routledge, London, 144-157.

ANSELL, N. (2004), 'Secondary schooling and rural youth transitions in Lesotho and Zimbabwe', Youth \& Society, 36, 183-202.

ANSELL, N. (2010), 'The discursive construction of childhood and youth in AIDS interventions in Lesotho's education sector: Beyond global-local dichotomies' ', Environment and Planning D - Society and Space, 28, 791-810.

ANSELL, N., HAJDU, F., ROBSON, E., VAN BLERK, L. \& MARANDET, E. (2012). 'Youth policy, neoliberalism and transnational governmentality: A case study of Lesotho and Malawi', in KRAFTL, P., HORTON, J. \& TUCKER, F. (eds.) Critical geographies of childhood and youth: Contemporary policy and practice, Bristol, The Policy Press.

ANSELL, N., VAN BLERK, L., HAJDU, F. \& ROBSON, E. (2011), 'Spaces, times and critical moments: A relational time-space analysis of the impacts of AIDS on rural youth in Malawi and Lesotho', Environment \& Planning A, 43, 525-544. 
Hajdu F, Ansell N, Robson E, van Blerk L (2013) 'Rural young people's prospects opportunities for employment and entrepreneurship in globalised southern Africa: the limitations of targeting policies' International Development Planning Review 35(2) 155-174

ARREHAG, L., DE WYLDER, S., DUREVALL, D. \& SJÖBLOM, M. (eds.) 2006. The impact of HIV/AIDS on livelihoods, poverty and the economy of Malawi., Stockholm: Swedish International Development Cooperation Agency.

BRYCESON, D. F. (2010), How Africa works: Occupational change, identity and morality, Rugby, Practical Action Publications.

CHAKA, N. (2011), 'Female migration, gender relations and remittances in Lesotho: On whose terms?', The 4th European Conference on African Studies (ECAS), The Nordic Africa Institute, Uppsala, Sweden.

CHAMBERS, R. \& CONWAY, G. (1992), 'Sustainable rural livelihoods: Practical concepts for the 21st century', IDS discussion paper, 296.

CHANT, S. \& JONES, G. A. (2005), 'Youth, gender and livelihoods in West Africa: Perspectives from Ghana and the Gambia', Children's Geographies, 3, 185-199.

CRENSHAW, K. (1989), 'Demarginalizing the intersection of race and sex: A black feminist critique of antidiscrimination doctrine, feminist theory and antiracist politics', University of Chicago Legal Forum, 139.

DAVIS, K. (2011). 'Intersectionality as buzzword: A sociology of science perspective on what makes a feminist theory successful', in Lutz, H., Herrera Vivar, M. T. \& Supik, L. (eds.) Framing intersectionality: Debates on a multi-faceted concept in gender studies, Farnham, Ashgate.

DE HAAN, L. \& ZOOMERS, A. (2005), 'Exploring the frontier of livelihoods research', Development and Change, 36, 27-47.

FERGUSON, J. (1990), The anti-politics machine: "Development," depoliticization, and bureaucratic power in Lesotho, Cambridge, Cambridge University Press.

GLOBAL FUND COORDINATING UNIT (2011) full details to be provided - can't access this right now

GOEBEL, A. (1998), 'Process, perception and power: Notes from 'participatory'research in a Zimbabwean resettlement area', Development and Change, 29, 277-305.

GOVERNMENT OF MALAWI (2003) National Policy on Orphans and other Vulnerable Children

GOVERNMENT OF MALAWI (2006) Malawi Growth and Development Strategy: From poverty to prosperity 2006-2011.

HAJDU, F. 2006. Local worlds: Rural livelihood strategies in Eastern Cape, South Africa. PhD Thesis, Linköping university.

HAJDU, F., ANSELL, N., ROBSON, E., VAN BLERK, L. \& CHIPETA, L. (2011), 'Income generating activities for young people in southern Africa: Exploring AIDS and other constraints', Geographical Journal, 177, 251-263.

KEARNEY, R. (2002), On stories, New York, Routledge.

LANGEVANG, T. \& GOUGH, K. V. (2012), 'Diverging pathways: Young female employment and entrepreneurship in sub-Saharan Africa', The Geographical Journal, 178, 242-252.

LI, T. M. (2007), The will to improve: Governmentality, development, and the practice of politics, Durham \& London, Duke University Press Books.

MAMDANI, M., RAJANI, R. \& LEACH, V. (2008), 'How best to enable support for children affected by HIV/AIDS? A policy case study in Tanzania ', IDS Bulletin, 39, 52-61.

MCCALL, L. (2005), 'The complexity of intersectionality', Signs, 30, 1771-1800.

MINISTRY OF HEALTH AND SOCIAL WELFARE (2006) National OVC Strategic Plan, Department of Social Welfare, Maseru, Lesotho.

NCUBE, W. (1998). 'The African cultural fingerprint? The changing concept of childhood', in NCUBE, W. (ed.) Law, culture, tradition and children's rights in eastern and southern Africa, Aldershot, Ashgate. 
Hajdu F, Ansell N, Robson E, van Blerk L (2013) 'Rural young people's prospects opportunities for employment and entrepreneurship in globalised southern Africa: the limitations of targeting policies' International Development Planning Review 35(2) 155-174

PETERS, P. E. (1997), 'Against the odds - matriliny, land and gender in the Shire highlands of Malawi', Critique of Anthropology, 17, 189-210.

PHOENIX, A. (2011). 'Psychosocial intersections: Contextualising the accounts of adults who grew up in visibly ethnically different households', in Lutz, H., Hererra Vivar, M. T. \& Supik, L. (eds.) Framing intersectionality: Debates on a multi-faceted concept in gender studies, Farnham, Ashgate.

PLATTEAU, J. P. (2004), 'Monitoring elite capture in community-driven development', Development and Change, 35, 223-246.

REPUBLIC OF MALAWI (2010) National Youth Policy. Lilongwe, Ministry of Youth Development and Sports

RIGG, J. (2006), 'Land, farming, livelihoods, and poverty: Rethinking the links in the rural South', World Development, 34, 180-202.

SCOONES, I. (2009), 'Livelihoods perspectives and rural development', Journal of Peasant Studies, 36, 171-196.

SCOTT, J. (1998), Seeing like a state: How well-intentioned efforts to improve the human condition have failed, New Haven and London, Yale University Press.

SKOVDAL, M. (2012), 'Pathologising healthy children? A review of the literature exploring the mental health of HIV-affected children in sub-Saharan Africa', Transcultural Psychiatry, 49, 461-491. 